\title{
THE IMPLEMENTATION OF TASK-BASED LANGUAGE TEACHING ON WRITING DESCRIPTIVE TEXT
}

\author{
${ }^{1,2}$ An Nida Nur Azizah, ${ }^{1}$ Kusrin, ${ }^{1}$ Abdul Kodir Al-Baekani \\ ${ }^{1}$ FKIP, Universitas Singaperbangsa Karawang, Indonesia \\ ${ }^{2}$ Corresponding Author Email: annidanurazizah4@gmail.com
}

\begin{tabular}{|c|c|}
\hline Article Info & Abstract \\
\hline $\begin{array}{l}\text { Article History } \\
\text { Received: September } 2021 \\
\text { Revised: October } 2021 \\
\text { Published: October } 2021\end{array}$ & $\begin{array}{l}\text { Students' responses to the implementation of task-based language teaching in the } \\
\text { writing learning process and the implementation of task-based language teaching } \\
\text { in the writing of descriptive text are the focus of this study. The research design } \\
\text { used in this study is the case study. The participants that participated in the study }\end{array}$ \\
\hline $\begin{array}{l}\text { Keywords } \\
\text { Writing Descriptive text; } \\
\text { Task-based language } \\
\text { teaching; } \\
\text { Students' responses; }\end{array}$ & $\begin{array}{l}\text { were in the tenth grade of a vocational high school. There were three male and } \\
\text { two female participants in this study. In addition, research utilizes observation, } \\
\text { interviews, and documentation to gather data for the studies. There are three } \\
\text { diplomas in the framework for task-based learning such as pre-task, task cycle, } \\
\text { and language focus. As shown in the findings of this study, task-based language } \\
\text { teaching has an influence on students' learning, particularly in regards to writing } \\
\text { descriptive text. Students become active and task-based language teaching also } \\
\text { influences students to involve a high level of creativity, students are required to } \\
\text { think critically and be responsive. However, Students find it difficult with the tasks } \\
\text { that have been assigned because it believes writing to be difficult and there are } \\
\text { aspects of writing that weren't well understood. }\end{array}$ \\
\hline
\end{tabular}

How to cite: Azizah, A.N.N., Kusrin., \& Al-Baekani, A.B. (2021). The Implementation of Task-Based Language Teaching on Writing Descriptive Text, JOLLT Journal of Languages and Language Teaching, 9(4) pp. 488-495. DOI: https://doi.org/10.33394/jollt.v\%vi\%i.4245

\section{INTRODUCTION}

Writing is one aspect of one's ability to communicate in English. Harmer (1998, p.79) in (Faraj, 2015) states that writing skills have been recognized as a basic language learning skill. He also pointed out the reasons for the importance of writing skills and teaches writing skills to EFL students, including reinforcement, language development, learning styles, and writing as a separate skills. (Heaton, 1998; (Sahardin et al., 2017), there are five general components or main areas of writing such as language use: the ability to write correct and appropriate collocations and sentences, mechanic skills: the ability to use correct conventions like punctuation and spelling, treatment of content: the ability to think creatively and to develop thought excluding irrelevant information, stylistic skills: the ability to manipulate sentences and paragraphs and to use language effectively, judgment skill: the ability to write in a manner appropriate for a particular purpose with a particular audience, and the ability to select, organize, and order relevant information with acceptable collocations. In writing, It is not just the writing of what an author wants to write that appears in his or her mind. on the other hand, a writer must be specific about the kind of information he or she want to communicate to her or his audience. (Harmer, 2007; (Asshiddiq \& Faridah Abd Rauf, 2019), there are four main elements in the writing process, those are planning: they will make a simple draft of the construction of their ideas, drafting: this can be called the first version of a paper is as draft, editing (reflecting and revising): reflection and revisions are often assisted by readers or editors who provide comments and suggestions, final version: produces the final version.

There are four different types of writing in the field of writing. Richards \& Schmidt (2002) in (Sufatmi Suriyanti, 2016), descriptive, narrative, expository, and argumentative are the four most common types of writing. However, descriptive text is the most basic of the four 
types of writing. In the study, significant learning occurs when educators choose teaching strategies that are appropriate to be implemented in the classroom, educators should makes students interested in learning descriptive text, and educators should implement strategies to assist student who are having difficulty writing so that students do not feel bored when they are learning to write. One of them is task-based language teaching. Task-Based Language Teaching (TBLT) is a communicative approach in the form of interactive activities that involve students to understand using a second language, and these activities are designed through giving assignments in learning activities (Nunan, 2004, p.4; (Halimi, 2019). Willis (2006: p. 38) cited in (Karunasree \& Francis, 2020) expresses that the task is the center of the eminence aspect attention during TBLT. He illustrates that each exercise has a contribution to make to some level. Willis (1998: p. 38) provides a three-diploma framework in a framework for task-based learning. They are as follows: pre-task, task cycle and language focus. The pre-task stage provides the problem and the task researcher's task to show the researcher to find related words and expressions that might make sense for the problem. In the initial assignment, the educator offers what the students will predict in the exam stage. Besides, educators can also prepare with the right techniques to create excellent supervisors, content, develop linguistics [syntax], mechanics, and jargon, and can move and encourage students to apply what they are OK with to complete the endeavor. Task-cycle, this stage accommodates assignments, compilation, and documents. Carrying out a major based language education offers three important situations for language acquisition situations: emergence, use, and thinking. Third, language focus in this phase contains investigations and exercises. Consideration of language allows for continued assessment of the number of precise highlights that prominently emerge in the language spoken during the challenge cycle. With this problem, amateurs could just work with language and set it up for that purpose, so they may be ready to focus on the administration of a particular language that carries between the lines.

In addition, the use of appropriate methods in teaching writing can solve the problem that occurs in the writing class. On the other hand, sometimes teachers are also experiencing difficulties in teaching writing the descriptive text for students who do not understand or are less enthusiastic about the material. However, students can develop the skills of writing descriptive texts consisting of essays and paragraphs after students complete the task, because task-based language teaching is an approach in language that encourages learning for students. Task-based language teaching can also be referred to as learning media.

\section{RESEARCH METHOD Research Design}

In this study, the researcher used qualitative research. Qualitative research is especially efficient at collecting culturally specific information on specific populations' values, opinions, behaviors, and social contexts (Namey, 2005). For the research design, the researcher used a case study. A case study is an empirical investigation that analyzes a current phenomenon (the "case") in depth and within its real-world context, particularly when the boundaries between phenomenon and context are unclear (Yin., 2014). In this study, the researcher tries to find out the utilization of task-based language teaching on the process of learning writing and to find out students' responses on the implementation of task-based language teaching on writing descriptive text.

\section{Research Participants and Instrument}

The participants were tenth grades at a vocational high school in Karawang. The researcher selected five participants, three male participants and two female participants to be interviewed. Interviews were conducted via Google Meet. To collect data in this research, there are ways to do data collection such as observation, interview and documentation. Researchers used instruments to collect data such as interview guidelines. 


\section{Data Analysis}

In this study, the collected data is analyzed. Data analysis used thematic analysis. Braun \& Clarke (2006) as cited in (Kiger \& Varpio, 2020), thematic analysis is a qualitative data analysis method that includes looking through a collection in order to identify, analyze, and report on recurring patterns. It is a method for describing data, but it also requires interpretation in the processes of selecting codes and constructing themes. In phases of thematic analysis adapted from Braun \& Clarke (2006), there are 6 phases such as familiarizing yourself with the data, generating initial codes, searching for themes, reviewing themes, defining and naming themes, and producing the report or manuscript.

\section{RESEARCH FINDINGS AND DISCUSSION Research Findings}

\section{Task-based language teaching affects students in the writing learning process}

The researcher acts as a teacher and makes observations during the learning process by observing students in their learning. The researcher introduces the topics and tasks discussed, the topics discussed reflect the world's tasks, so that it attracts students to be real, researchers can learn and task to follow the learning because it can be applied in everyday life. Writing skills can provide benefits to train and encourage students to express themselves to express their ideas when writing.

Table 1

The three students said they were interested in learning to write

\begin{tabular}{|c|c|l|}
\hline No & Student & \multicolumn{1}{c|}{ Responses } \\
\hline 1 & B & $\begin{array}{l}\text { "I'm interested in learning, writing makes me to think critically } \\
\text { and tries to pull out of ideas." }\end{array}$ \\
\hline 2 & C & $\begin{array}{l}\text { "Feel interested in learning writing, I can develop ideas." } \\
\text { ["I'm still interested in learning writing because I'm practicing my } \\
\text { own writing." }\end{array}$ \\
\hline
\end{tabular}

The researchers provided clear instructions on what the student needed do at this stage of the task in order to accomplish it. Following that, students are allowed to start work on their given task. The teacher's role in this situation is to observe and monitor students while their complete the task. Students are involved in the class. They are interested in paying attention, participating in the discussion of the material, and following the teacher's directions. Teachers in task-based language teaching are facilitators. Students use their initiative to accomplish their task. Although task-based language teaching is learner-centred, it does not mean that students are allowed to carry out activities without prior guidance or explanation. students also active when it entered the discussion and when given a task. 
Table 2

Three students are active in the learning process

\begin{tabular}{|c|c|l|}
\hline No & Student & \multicolumn{1}{c|}{ Responses } \\
\hline 1 & A & $\begin{array}{l}\text { "I am active in the learning process even though I don't like } \\
\text { English lessons, but I'm still working on my assignments." }\end{array}$ \\
\hline 2 & C & $\begin{array}{l}\text { "In my opinion, because it was interspersed with material, I also } \\
\text { understood the instructions that you gave so that I became active } \\
\text { in learning." } \\
\text { "Given a task by you I became active because I already } \\
\text { understood the instructions you gave so I did the task." }\end{array}$ \\
\hline 3 & D &
\end{tabular}

During the learning process, the teacher also asked questions about the material being discussed. Students also respond with their own answers, this shows that students are active in the learning process. There are some students who immediately asked if feel less familiar with the material that has been previously described. When students have completed their tasks, the teacher asks them to show the results of the tasks they have done.

Task-based language teaching has been shown to influence students in the learning process especially in teaching writing for this task-based learning involves a high degree of creativity, students are required to think critically and responsive in learning.

\section{Students' responses in writing learning involvement}

There are student responses in their involvement regarding difficulties in learning writing. There are student responses in their involvement regarding difficulties in learning writing. Regarding the involvement of student responses in writing, there are two students who have difficulties in learning writing because they are confused about one of the aspects of writing is the ability to use the correct conventions such as punctuation and spelling.

Table 3

Students respond to difficulties in learning writing

\begin{tabular}{|c|c|l|}
\hline No & Student & \multicolumn{1}{c|}{ Responses } \\
\hline 1 & A & $\begin{array}{l}\text { "I have difficulty learning writing, confused about determining } \\
\text { the letters, such as using lowercase and uppercase letters." }\end{array}$ \\
\hline 2 & B & $\begin{array}{l}\text { "It is difficult for me to learn writing, sometimes I am confused } \\
\text { about putting the punctuation marks in a sentence." }\end{array}$ \\
\hline 3 & D & $\begin{array}{l}\text { "I find it difficult to learn writing, how to write the right } \\
\text { sentence." }\end{array}$ \\
\hline
\end{tabular}

The students' responses indicated that learning writing was difficult if they did not understand the writing aspect. 


\section{Student responses in the involvement of learning to write descriptive text}

Student responses in the involvement of learning descriptive text writing. Descriptive text has a social function to describe a person, place, or a particular object.

Table 4

There is one student who understands the material

\begin{tabular}{|c|c|l|}
\hline No & Student & \multicolumn{1}{c|}{ Responses } \\
\hline 1 & E & $\begin{array}{l}\text { "I have understood the learning material that you gave. In my } \\
\text { opinion, descriptive text is a text that describes an object, person } \\
\text { or place." }\end{array}$ \\
\hline
\end{tabular}

There are responses of students regarding their difficulties in making the descriptive text that has been the teacher commanded. There are students who have difficulty in planning what they will write, confused to find their ideas and use the linguistic features of descriptive texts. Need the ability to think creatively and develop ideas.

Table 5

Student responses about making descriptive text

\begin{tabular}{|c|c|l|}
\hline No & Student & \multicolumn{1}{c|}{ Responses } \\
\hline 1 & A & $\begin{array}{l}\text { "My difficulty in making descriptive texts is finding ideas that will } \\
\text { be discussed and arranging the words." } \\
\text { "If I was to difficulty making descriptive text translated into } \\
\text { English." } \\
\text { "It's hard to make descriptive texts looking for ideas, and I'm } \\
\text { confused about compiling it into a paragraph." }\end{array}$ \\
\hline 3 & B & D
\end{tabular}

This shows that indeed making descriptive texts is not easy, it requires ideas, moreover students have to translate the text into English.

\section{Student responses to the implementation of task-based language teaching to write descriptive text}

The task is a goal-oriented activity with a definitive result, in which learners use language to achieve real results. Given the task to find out how the students' understanding of learning has been implemented.

Table 6

Student responses about tasks

\begin{tabular}{|c|c|l|}
\hline No & Student & \multicolumn{1}{c|}{ Responses } \\
\hline 1 & A & $\begin{array}{l}\text { "For me, the task given is quite difficult because there are other } \\
\text { tasks too." } \\
\text { "The task given is quite difficult, I still don't understand the task } \\
\text { that determines one of the linguistic elements in a text." }\end{array}$ \\
\hline 2 & B & $\begin{array}{l}\text { "For the task you gave is difficult too, I feel confused about the } \\
\text { task that determines the generic structure of the descriptive text." }\end{array}$ \\
\hline 3 & D &
\end{tabular}


Students responded that the given task was difficult because they were still confused with the elements of writing language

\section{Discussion}

This section shows the outcomes of the study that has been conducted by the researchers. The findings above are obtained from the results of two research questions. Concerning the first research question, the results of the study show that task-based language teaching had an influence on students' writing skills during the writing learning process. Concerning the study results of the second research question, the three findings obtained in the form of student responses in writing learning involvement, student responses in the involvement of learning to write descriptive text, and student responses to the implementation of task-based language teaching to write descriptive text.

The first data collection of this research used observation. The observation used in this research is a Participant Observer. The researcher as a teacher and as an observer of students who are directly involved in learning activities. According to (Creswell, 2012), Participant observer is the observational role adopted by the researcher when taking part in activities in the setting being observed. The researcher acts as an "inside" observer who is really involved in the activities at the research site. At the same time participate in activities, and record information. Based on the data collected from these observations, students are indeed involved in the learning process by utilizing assignments so that they can influence students in their learning, especially writing learning. It can be seen from the attitude and enthusiasm of students in learning. Students feel interested in learning writing so that they are active in learning. (Douglas \& Kim, 2014) cited in (Davut Nhem, 2020), found that most teachers considered TBLT a learner-centered approach because it allowed students to be more involved in learning activities. The authenticity of tasks that require students to interact and participate in the learning process can also be referred to as activities carried out by students (Guariento \& Morley, 2001).

After that, responses to the second research question were obtained from students who were involved in the process of writing learning. In terms on the things that influence them, three students reported difficulty in learning writing, whereas two additional students reported ease in learning writing, resulting in a greater number of student answers indicating problems in learning writing. As underlined by (Heaton, 1998) cited in (Sahardin et al., 2017), there are five general components or main areas of writing, one of them mechanical skill is the ability to use correct conventions such as punctuation and spelling.

Furthermore, Responses of students to the involvement of learning in the production of descriptive text There is one student who has already shown an understanding of the material that has been given. Although other students also understand the descriptive text material, the use of punctuation and spelling errors causes them to be less understanding of what they are learning. In addition, students also responded to difficulties in producing descriptive text. there were three students who made a statement about difficulties in producing descriptive texts. Lines (2003:33) cited in (Hariyadi et al., 2018), Writing is a combination of the process and product of finding an idea, putting it on paper and working on it until it is presented in a way that is polished and understandable to the reader. That is, what is important from writing for students is to express the feelings generated in their own words on paper. From the previous ideas, the writer concludes that writing is a thinking process to find ideas, think about how to express them in good writing and compose a clear statement of ideas and paragraphs. In addition it is translated into English text into trouble the students themselves. 
On the other hand, there is also a student responses to the implementation on the task of learning writing descriptive text. Students assume the tasks assigned by the teacher is hard enough, still confused on the generic structure and linguistic features of descriptive text. (Feez \& Joyce, 1998) in (Sahardin et al., 2017), there are 8 linguistic features of descriptive text, such as the use of nouns, simple Present tense, noun phrases detail to provide information about the subject, various adjectives used to number or categorize the subject, relating verbs to provide information about the subject, think and feel verbs to communicate personal feelings about the subject, action verbs, adverbials to provide additional information about the subject's behavior, and similes or metaphors. If students understand some of the language features, it will make it easier for students to write correctly so that they don't feel confused and had no difficulty in doing the task.

\section{CONCLUSION}

The data that has been collected, it shows that the utilization of task-based language teaching in the writing learning process can affect students in their learning, especially in writing descriptive text. Task-based language teaching can also help teachers in their learning process to control the students and help students interact spontaneously. Students showed their participation in the learning process. Moreover, they showed activeness during the discussion. In addition, when the teacher gave questions to the students, the students directly answer the question. The application of task-based language teaching can be considered as an effective way for the learning process for tenth-grade students. Besides, recognizing the importance of being responsible for the extent of the material that they understand of learning that has been given and the learning process by creating a meaningful task.

However, all respondents stated that their obstacle was that they felt difficult with the tasks they had been given. Their difficulty is writing, especially in making descriptive texts because writing does require students to be creative and come up with ideas. In addition, respondents also found it difficult to use linguistic elements, writing aspects, and elements in the writing process.

\section{REFERENCES}

Asshiddiq, M., \& Faridah Abd Rauf. (2019). Using Video Critics Strategy in Developing Students' Writin. Journal of Linguistics and English Teaching Studies, 25-43.

Creswell, J. W. (2012). Educational Research: Planning, Conducting, and Evaluating Quantitative and Qualitative Research fourth edition. (Vol. 148).

Davut Nhem. (2020). Using Task-Based Language Teaching in English Writing Classrooms: Students' Perception of Motivation, Writing Behavior, and Challenges. Journal of Foreign Language Teaching and Translation Studies, 5(3), 47-66. https://doi.org/10.22034/efl.2020.246165.1054

Faraj, A. K. A. (2015). Scaffolding EFL Students' Writing through the Writing Process Approach. Journal of Education and Practice, 6(13), 131-142.

Halimi, I. S. S. (2019). The Use of Task Based Language Teaching (TBLT) as to Improve Descriptive Writing Skills. 4(2), 780-796.

Hariyadi, P., Wennyta, \& Fitri, N. (2018). An Analysis of Students' Ability In Writing Descriptive Text at The Tenth Grade Students of SMAN 11 Jambi Academic Year 2017/2018. Repository Universitas Islam Sultan Syarif Kasim, 2(2), 39-46. 
Karunasree, K., \& Francis, S. (2020). Developing writing skills of ESL learners using task based language teaching. Journal of Critical Reviews, 7(6), 6-8. https://doi.org/10.31838/jcr.07.06.02

Kiger, M. E., \& Varpio, L. (2020). Thematic analysis of qualitative data: AMEE Guide No. 131. Medical Teacher, 42(8), 846-854. https://doi.org/10.1080/0142159X.2020.1755030

Namey, N. M. C. W. K. M. M. G. G. E. (2005). Qualitative Research Methods: A Data Collector's Field Guide.

Sahardin, R., Hanum, C. S., \& Gani, S. A. (2017). Using Think-Pair-Share for writing descriptive texts. Studies in English Language and Education, 4(1), 54. https://doi.org/10.24815/siele.v4i1.7004

Sufatmi Suriyanti, A. Y. (2016). Exploring teacher strategies in teaching descriptive writing in Indonesia. Malaysian Journal of Learning and Instruction, 13.

Yin., R. K. (2014). Case Study Research: Design and Methods Fifth edition (Vol. 148). SAGE. 